\title{
Effects of Oral Diazepam or Inhalatory Nitrous Oxide- Oxygen for Conscious Sedation During Third Molar Surgery: A Randomized Controled Trial, Split Mouth Design
}

\author{
Efectos del Diazepam Oral o la Inhalación de Óxido Nitroso-Oxígeno para la \\ Sedación Consciente Durante la Cirugía del Tercer Molar: Un Ensayo Controlado \\ Aleatorio, Diseño de Boca Dividida
}

\author{
Samantha Cristine Santos Xisto Braga Cavalcanti ${ }^{1}{ }^{2} ;$ Fernanda Cristina Cunha ${ }^{3}$ \& João Gualberto C. Luz ${ }^{1}$
}

CAVALCANTI, S. C. S. X. B.; CUNHA, F. C. \& LUZ, J. G. C. Effects of oral diazepam or inhalatory nitrous oxide-oxygen for conscious sedation during third molar surgery: A randomized controled trial, split mouth design. Int. J. Odontostomat., 14(1):1926, 2020.

ABSTRACT: Anxiety in dental surgery may lead to behavioral and physiological changes for the patient and constitute a frequent challenge for the oral surgeon. The objective of this study was to compare the effect of inhalatory nitrous oxide and oxygen $\left(\mathrm{N}_{2} \mathrm{O} / \mathrm{O}_{2}\right)$ with oral diazepam conscious sedation in vital signs of patients undergone third molar extraction. Outpatients who needed removal of partially impacted, bilateral lower third molars, during the period of one year, were included. Each patient underwent conscious sedation with either oral diazepam or inhalatory $\mathrm{N}_{2} \mathrm{O} / \mathrm{O}_{2}$ on a randomized controlled trial, split-mouth design. Systolic and diastolic blood pressure, heart rate and oxygen blood saturation were the changes measured before, at the beginning and the end of the procedure. Also, surgical procedure duration was recorded. Data from vital signs were submitted to analysis of variance and the duration of the surgery to paired Student's t-test. Twenty-five healthy outpatients (13 women and 12 men) with a mean age of 21.6 years were studied. There was an increase in systolic and diastolic pressure and in heart rate in the beginning; these values decreased and stabilized at the end of the surgical procedure in both treatments $(p<0.001)$ being lower in $\mathrm{N}_{2} \mathrm{O} / \mathrm{O}_{2}$ but without difference between treatments. The surgical procedure duration was lower and occurred an expected increase of oximetry under $\mathrm{N}_{2} \mathrm{O} / \mathrm{O}_{2}$ sedation $(\mathrm{p}<0.001)$. Both treatments were effective for the conscious sedation but $\mathrm{N}_{2} \mathrm{O} / \mathrm{O}_{2}$ showed better outcomes, mainly in duration of the surgery.

KEY WORDS: conscious sedation; nitrous oxide; diazepam; molar, third.

\section{INTRODUCTION}

Dental fear or phobia has long been ranked the fourth most common fear, and may cause an emotional state of anxiety and discomfort to the patient (Tanidir et al., 2016; Astramskaite et al., 2016). Anxiety is an important part of the body's reaction. It is described as stress, apprehension, nervousness and concerns caused by an intangible or diffuse advancing threat or approaching danger, accompanied by sympathetic nervous and endocrine system activation (Astramskaite` \& Juodžbalys, 2017; Kazancioglu et al., 2017).

Impacted mandibular third molar surgery is one of the most common oral and maxillofacial surgical procedures (Kim et al., 2011; Choi et al., 2015). This procedure is occasionally uncomfortable, stressful and certainly involves some degree of anxiety to the patient. This situation may increase the complexity of procedures, resulting in stress to the operating surgeon and consequently decreasing the productivity of effective work and leading to longer operation times (Aznar-Arasa et al., 2014; Dantas et al., 2017).

Higher levels of dental anxiety can affect the psychological state of the patient and promote many physiological manifestations such as muscle tension, palmar sweat, increased respiratory rate, systolic and diastolic blood pressure alterations, and heart rate and oxygen saturation variations. It is, therefore, desirable to reduce the amount of discomfort related to this type

${ }^{1}$ Department of Oral and Maxillofacial Surgery, School of Dentistry, University of São Paulo, Brazil.

${ }^{2}$ FMU School of Dentistry, São Paulo, SP, Brazil.

${ }^{3}$ Oral and Maxillofacial Surgery Specialization Clinic, APCD (Paulista Dental Association), São Paulo, SP, Brazil. 
CAVALCANTI, S. C. S. X. B.; CUNHA, F. C. \& LUZ, J. G. C. Effects of oral diazepam or inhalatory nitrous oxide-oxygen for conscious sedation during third molar surgery: A randomized controled trial, split mouth design. Int.J. Odontostomat., 14(1):19-26, 2020.

of surgery (Alemany-Martínez et al., 2008; Kim et al.; Hollander et al., 2016). The local anesthetic administration during third molar extractions can increase the levels of fear and anxiety. Thus, the oral and maxillofacial surgeon has to deliver it safely and effectively (Inverso et al., 2016).

Nowadays, there are many medicated and nonmedicated ways to ease anxiety in dental surgery. The control of this negative stimulus can be achieved through a simple conversation, hypnosis, aromatherapy, musical therapy, behavioral management or the use of medication for conscious sedation and, eventually general anesthesia (Kim et al.; de Morais et al., 2015; Tanidir et al.; Astramskaite" \& Juodžbalys). Anxiolysis, defined as the use of pharmacological agents to reduce anxiety, is a helpful adjunct to local anesthesia for dental surgery (Studer et al., 2012). The stress attenuation by means of anxiolytics or sedation can be employed to reduce the cardiovascular response associated with patient anxiety (Alemany-Martínez et al.).

Conscious sedation is one of the most effective ways to increase patient and surgeon satisfaction with the operation (Göktay et al., 2011). Many sedative drugs in different regimens and administered by different delivery routes have been used for conscious sedation (Young, 2005; Fan et al., 2013). The administration of inhalation or oral sedative agents are frequently employed in the dental practice during a surgical procedure (Hulland et al., 2002).

The purpose of this study was to compare the inhalatory nitrous oxide and oxygen $\left(\mathrm{N}_{2} \mathrm{O} / \mathrm{O}_{2}\right)$ with oral diazepam conscious sedation in the alteration of vital signs, such as blood pressure and heart rate, and oximetry in patients undergone third molar extraction. The investigators hypothesized that $\mathrm{N}_{2} \mathrm{O} / \mathrm{O}_{2}$ would only influence the results of oximetry because the association with oxygen but both treatments would be effective for the conscious sedation. The specific aims were to measure and to compare systolic, diastolic blood pressure, heart rate, oxygen blood saturation and duration of the surgery in $\mathrm{N}_{2} \mathrm{O} / \mathrm{O}_{2}$ and diazepam treatments.

\section{MATERIAL AND METHOD}

Study design/sample: The study population was composed of outpatients presenting to surgical removal of bilateral, symmetrically placed, mesioangulated mandibular third molars with partial bone impaction without complications, classes $\mathrm{BI}$ and BII (Pell \& Gregory, 1942) during the period of one year. To be included in this study, patients were radiographically examined by means of panoramic radiographs, had to be above the age of 17 years-old, had to be categorized as American Society of Anesthesiologists class I and had to require the surgical extraction of both lower third molars. Exclusion criteria were refusal to participate, contraindications to test medications, smoking, alcohol, and a history of allergies or genetic factors. Informed written consent was obtained from all patients.

Each patient had two operations separeted by at least 3 weeks. The trial was randomly assigned to either the right or left side surgery on a split-mouth design. For one side, the patient received conscious sedation with oral $5 \mathrm{mg}$ of diazepam (Valium ${ }^{\circledR}$, Roche Produtos Químicos e Farmacêuticos SA, Rio de Janeiro, Brazil) 1 hour before the surgery and for the other side the patient received inhalatory conscious sedation with a medical mixture gas of nitrous oxide and oxygen. $\mathrm{N}_{2} \mathrm{O} / \mathrm{O}_{2}$ was administered by means of a nasal hood and titrated in $10 \%$ increments of nitrous oxide to the level that would allow completion of treatment and patient conscious cooperation. The $\mathrm{N}_{2} \mathrm{O}$ / $\mathrm{O}_{2}$ flow control device was set up to limit a gas flow to no higher than a maximum $\mathrm{N}_{2} \mathrm{O}$ concentration of $70 \%$ (MDM Matrx®, Orchard Park, NY, USA). When the surgical treatment was complete at the end of suture, the nitrous oxide flow was switched off and oxygen $100 \%$ was administered for $3 \mathrm{~min}$.

One hour before each operation, $1 \mathrm{~g}$ oral ampicillin (Ampicilina, Medley S. A., Campinas, Brazil) and $4 \mathrm{mg}$ oral dexamethasone (Decadron $®$, Prodome, Campinas, Brazil) were administred. The surgical protocol was standardized and all operations were perfomed by the same surgeon and assistant. Benzocaine $20 \%$ topical anaesthetic gel was applied to the dried mucosa for 2 minutes and then lidocaine 2 $\%$ plus 1:100.000 epinephrine was used for the inferior alveolar and buccal nerve blocks. After checking the anesthetic state of the mucosa, the surgeon made an incision and created a mucoperiostal flap. After alveolectomy, the third molar was removed, and the flap was repositioned and sutured. After the surgery, routine postoperative instructions, including the use of $500 \mathrm{mg}$ oral ampicillin 4 times per day for 7 days and $500 \mathrm{mg}$ acetaminophen every 4 hours as needed were provided to the patient. 
CAVALCANTI, S. C. S. X. B.; CUNHA, F. C. \& LUZ, J. G. C. Effects of oral diazepam or inhalatory nitrous oxide-oxygen for conscious sedation during third molar surgery: A randomized controled trial, split mouth design. Int.J. Odontostomat., 14(1):19-26, 2020.

Variables/Data collection: In this study, the predictor variable was the conscious sedation technique, comparing the effect of inhalatory nitrous oxide and oxygen $\left(\mathrm{N}_{2} \mathrm{O} / \mathrm{O}_{2}\right)$ with oral diazepam in vital signs, such as blood pressure and heart rate, and oximetry of patients undergone third molar extraction. The primary outcome variables were a set of physiologic measures, such as systolic and diastolic blood pressure, heart rate and oxygen blood saturation, measured before, at the beginning and the end of the procedure.

A non-invasive monitor (Avant 2020 pulsioximeter, Nonin Medical Inc., Minnesota, USA) was used to record systolic, diastolic blood pressure (in millimeters of mercury $-\mathrm{mmHg}$ ), heart rate (in beats per minute - bpm) and oxygen blood saturation (in percentage - \%) at three different times: one hour before the surgery at the waiting room, in the beginning of the surgery (when the patient sat down at the dental chair) and at the end of the surgical procedure after suturing. Also, the duration of the surgery in minutes (min) was recorded, starting when the patient sat down in the dental chair until the suture was finished.

Data analysis: Results were analyzed using BioEstat 5.3 software (Sociedade Civil Mamirauá / MCT $\mathrm{CNPq}$, Belém, Brazil). The criterion of significance was a probability of 0.05 . A two-way analysis of variance (ANOVA) was performed to evaluate possible differences among values of systolic and diastolic blood pressure, heart rate and blood oxygen saturation at three different times (one hour before, in the beginning and at the end of the surgical procedure) within $\mathrm{N}_{2} \mathrm{O} / \mathrm{O}_{2}$ and diazepam sedations. Tukey's test was used to determine statistical significance between each period and between the treatments. Data obtained from the duration of the surgery were tested by the paired Student's t-test to compare the mean values from the $\mathrm{N}_{2} \mathrm{O} / \mathrm{O}_{2}$ and diazepam sedations.

\section{RESULTS}

Twenty-five healthy outpatients ( 13 women and 12 men) with ages ranging between 18 and 25 yearsold were studied. Fifty surgical procedures were performed in patients with a mean age of 21.6 years. There were no reported cases of unpleasant side effects such as rash, dizziness, nausea, vomiting, headache or bizarre behavioral responses to diazepam or $\mathrm{N}_{2} \mathrm{O} / \mathrm{O}_{2}$ conscious sedation.
Systolic blood pressure: The mean values of systolic blood pressure before surgery were within normal range, being $112.4 \pm 14.8 \mathrm{mmHg}$ for the diazepan group and $112.0 \pm 13.8 \mathrm{mmHg}$ for the $\mathrm{N}_{2} \mathrm{O} / \mathrm{O}_{2}$ group, presented a slight increase at the beginning of surgery with $122.8 \pm 12.4 \mathrm{mmHg}$ for the first group and $122.4 \pm$ $9.7 \mathrm{mmHg}$ for the second group, returning to initial levels in the diazepan group with $110.8 \pm 10.8 \mathrm{mmHg}$ and lower values in the $\mathrm{N}_{2} \mathrm{O} / \mathrm{O}_{2}$ group with $108.4 \pm 10.7$ $\mathrm{mmHg}$. The two-way ANOVA showed that there was no statistical difference in systolic blood pressure between the treatments with $\mathrm{N}_{2} \mathrm{O} / \mathrm{O}_{2}$ and diazepam conscious sedation in the different times of the surgical procedure $(p=0.510)$. There was statistical difference among the different periods of the surgical procedure for the operations with $\mathrm{N}_{2} \mathrm{O} / \mathrm{O}_{2}$ and diazepam conscious sedation $(p<0.001)$. Tukey's test showed that there was statistical difference between the beginning of the surgery and before the surgery $(p<0.001)$, and between the beginning of the surgery and the end of the surgery $(p<0.001)$. There was no statistical difference between the end of the surgery and before the surgery $(p=0.184)$ (Fig. 1).

Diastolic blood pressure: The mean values of diastolic blood pressure before surgery were within normal range, being $76.0 \pm 7.6 \mathrm{mmHg}$ for the diazepan group and $76.4 \pm 7.0 \mathrm{mmHg}$ for the $\mathrm{N}_{2} \mathrm{O} / \mathrm{O}_{2}$ group, presented a slight increase at the beginning of surgery with $80.4 \pm 6.1 \mathrm{mmHg}$ for the first group and $80.8 \pm 4.0$ $\mathrm{mmHg}$ for the second group, returning to initial levels in the diazepam group with $76.0 \pm 5.8 \mathrm{mmHg}$ and lower values in the $\mathrm{N}_{2} \mathrm{O} / \mathrm{O}_{2}$ group with $74.8 \pm 7.1 \mathrm{mmHg}$. The two-way ANOVA showed that there was no statistical difference in diastolic blood pressure between the treatments with $\mathrm{N}_{2} \mathrm{O} / \mathrm{O}_{2}$ and diazepam conscious sedation in the different times of the surgical procedure $(p=0.885)$. There was statistical difference among the different periods of the surgical procedure for the operations with $\mathrm{N} 2 \mathrm{O} / \mathrm{O} 2$ and diazepam conscious sedation $(p<0.001)$. Tukey's test showed that there was statistical difference between the beginning of the surgery and before the surgery $(p<0.001)$, and between the beginning of the surgery and the end of the surgery $(p<0.001)$. There was no statistical difference between the end of the surgery and before the surgery $(p=0.694)$ (Fig. 1).

Heart rate: The mean values of heart rate before surgery were within normal range, being $88.36 \pm 16.32$ bpm for the diazepan group and $87.64 \pm 17.57 \mathrm{bpm}$ for the N2O/O2 group, presented a slight increase at the beginning of surgery with $93.24 \pm 15.36 \mathrm{bpm}$ for 


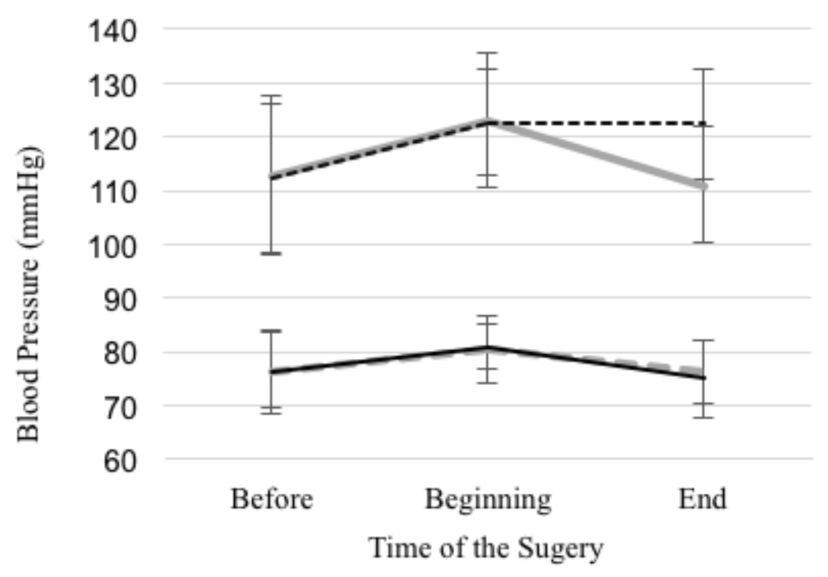

Systolic ----- Systolic
-- Diastolic $\longrightarrow$ Diastolic

Fig. 1. Mean values of systolic and diastolic blood pressures $(\mathrm{mmHg})$ under conscious sedation with diazepam and $\mathrm{N}_{2} \mathrm{O} /$ $\mathrm{O}_{2}$ according to the time of the surgery. Error bars represent standard deviations. $\left(^{*}\right)$ Statistical difference between the beginning and the other different times of the surgery according to Tukey's test.

the first group and $93.84 \pm 18.75 \mathrm{bpm}$ for the second group, returning to lower values in the diazepan group with $73.04 \pm 8.25 \mathrm{bpm}$ and in the $\mathrm{N}_{2} \mathrm{O} / \mathrm{O}_{2}$ group with $67.80 \pm 5.98 \mathrm{bpm}$. The two-way ANOVA showed that there was no statistical difference in the heart rate between the treatments with $\mathrm{N}_{2} \mathrm{O} / \mathrm{O}_{2}$ and diazepam conscious sedation in the different times of the surgical procedure $(p=0.300)$. There was statistical difference among the different periods of the surgical procedure for the operations with $\mathrm{N}_{2} \mathrm{O} / \mathrm{O}_{2}$ and diazepam conscious sedation $(p<0.001)$. Tukey's test showed that there was statistical difference between the beginning of the surgery and before the surgery $(p=0.017)$, between the beginning of the surgery and the end of the surgery $(p<0.001)$, and between the end of the surgery and before the surgery $(p<0.001)$ (Fig. 2).

Oxygen saturation: The mean values of oxygen saturation before surgery were within normal range, being $95.72 \pm 1.21 \%$ for the diazepan group and $96.36 \pm 1.19 \%$ for the $\mathrm{N}_{2} \mathrm{O} / \mathrm{O}_{2}$ group, presented an increase at the beginning of surgery with $96.44 \pm 0.96 \%$ for the first group and 98.64 $\pm 0.49 \%$ for the second group, returning to lower values in the diazepan group with $96.20 \pm 0.50 \%$ and maintaining higher values in the $\mathrm{N}_{2} \mathrm{O} / \mathrm{O}_{2}$ group with $96.80 \pm 0.41 \%$. The two-way ANOVA showed that there was statistical difference in oxygen saturation between the treatments with $\mathrm{N}_{2} \mathrm{O} / \mathrm{O}_{2}$ and diazepam conscious sedation in the different times of the surgical procedure $(p<0.001)$, and among the different periods of the surgical procedure $(p<0.001)$. Tukey's test showed statistical differences between diazepam and $\mathrm{N}_{2} \mathrm{O} / \mathrm{O}_{2}$ groups ( $p$ $=0.023$ ) before the surgery, an increase in diazepam group $(p=0.003)$ and in $\mathrm{N}_{2} \mathrm{O} / \mathrm{O}_{2}(p<0.001)$ at the beginning of the surgery was observed but with higher values to $\mathrm{N}_{2} \mathrm{O} / \mathrm{O}_{2}(\mathrm{p}<0.001)$, similar findings were maintained at the end of the surgery with the same higher values to $\mathrm{N}_{2} \mathrm{O} / \mathrm{O}_{2}(p<0.001)$ (Fig. 3).

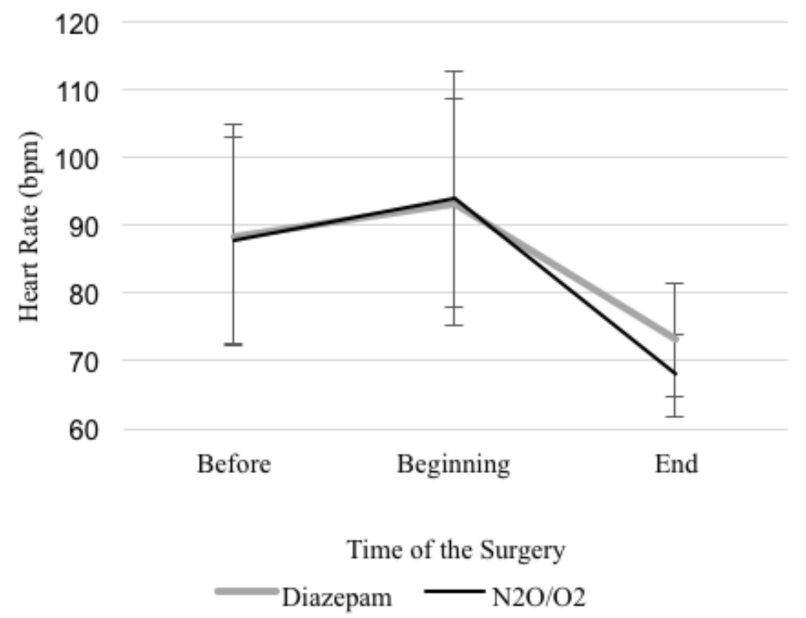

Fig. 2. Mean values of heart rate (bpm) under conscious sedation with diazepam and $\mathrm{N}_{2} \mathrm{O} / \mathrm{O}_{2}$ according to the time of the surgery. Error bars represent standard deviations. (\#) Statistical difference between the different times of the surgery according to Tukey's test for diazepam and $\mathrm{N}_{2} \mathrm{O} / \mathrm{O}_{2}$ treatments.

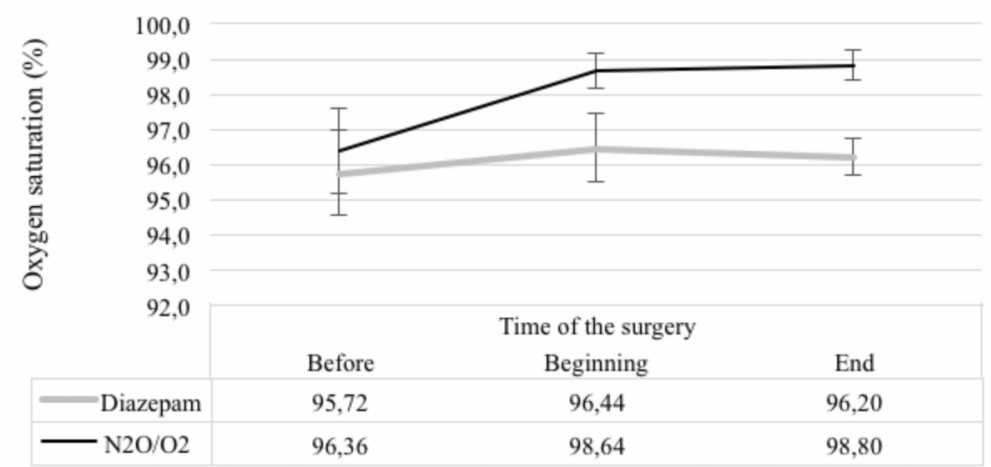

Fig. 3. Mean values and standard deviations of oxygen saturation ( \%) under conscious sedation with diazepam and $\mathrm{N}_{2} \mathrm{O} / \mathrm{O}_{2}$ according to the time of the surgery. Error bars represent standard deviations. Distinct letters mean statistical difference between results according to Tukey's test. 
CAVALCANTI, S. C. S. X. B.; CUNHA, F. C. \& LUZ, J. G. C. Effects of oral diazepam or inhalatory nitrous oxide-oxygen for conscious sedation during third molar surgery: A randomized controled trial, split mouth design. Int.J. Odontostomat., 14(1):19-26, 2020.

Duration of the surgery: The mean total duration of the surgery was $73.40 \pm 10.58 \mathrm{~min}$ for the diazepam group and $50.00 \pm 7.07$ min for the $\mathrm{N}_{2} \mathrm{O} / \mathrm{O}_{2}$ group. The paired Student's t-test showed that there was significant difference between the diazepam and $\mathrm{N}_{2} \mathrm{O} / \mathrm{O}_{2}$ conscious sedation $(p<0.001)$.

\section{DISCUSSION}

In this study, patients were submitted to bilateral third molar extraction under randomic conscious sedation with inhalatory $\mathrm{N}_{2} \mathrm{O} / \mathrm{O}_{2}$ or oral diazepam. Outcomes measured and compared were systolic, diastolic blood pressure, heart rate, oxygen blood saturation and duration of the surgery. The null hyphothesis that $\mathrm{N}_{2} \mathrm{O}$ / $\mathrm{O}_{2}$ would influence only the results of oximetry due to the association with oxygen was rejected because when the patient was sedated with $\mathrm{N}_{2} \mathrm{O} / \mathrm{O}_{2}$ enhanced outcomes were also obtained for duration of the surgery. There was an increase in systolic and diastolic pressure and in heart rate in the beginning; these values decreased and stabilized at the end of the surgical procedure in both treatments, being lower in $\mathrm{N}_{2} \mathrm{O} / \mathrm{O}_{2}$, but with no difference between groups. The surgical procedures were performed in twenty-five healthy outpatients ( $52 \%$ females) between 18 and 25 years of age using the split-mouth design. This kind of randomized clinical trial has been used in oral health research, comprising each of two treatments are randomly assigned to either the right or left halves of the patient, decreasing the bias of familiarity with the surgery (Pereira-Santos et al., 2013; Lesaffre et al., 2009). The attractiveness of this design is that it removes a lot of inter-individual variability from the estimates of the treatment effect (Lesaffre et al.). One limitation of this study was the non-obtention of patient satisfaction relative to sedation technique. Further studies should include this aspect relative to these techniques. With regard to anxiety in patients undergoing a tooth extraction procedure, studies presented a lot of information about patients with different levels of trait anxiety like gender, age, social classes, marital status, previous dental experience, previous information about the surgical procedure and other ones (Alemany-Martínez et al.; Kim et al.; Studer et al.; Choi et al.; Tarazona et al., 2015; Astramskaite et al., 2016). A rigorous investigation of the patients medical and family history is important to contribute to a favorable outcome (de Morais et al.). In the present sample, none of the patients experienced risk factors such as contraindications to diazepam or $\mathrm{N}_{2} \mathrm{O} / \mathrm{O}_{2}$, smoking, alcohol, history of allergies or genetic factors.
The conscious sedation technique selected has to be safe. Oral benzodiazepines have a large margin of clinical safety and are easy to administer, have low coast, with fewer drug reactions and longer onset time (Jerjes et al., 2005). But they potentiate the alcohol effect and may promote a paradoxical reaction. In addition, sedation with benzodiazepines requires that patients must be accompanied to appointments with the recommendation of a ride home and not to operate motor vehicles or hazardous machinery for the duration of the pharmacological effects of the drugs, thus prolonging postoperative recovery and its possibles side effects. Despite their low toxicity, patients may experience adverse reactions such as rash, nausea, vomiting, dizziness, sweating, anaphylactic shock or headache (Göktay et al.; de Morais et al.; Inverso et al.; Dantas et al.). In addition, oral sedation is complicated by variable absorption and the inability to titrate the dose to the desired effect, characteristics that may produce unpredictable levels of sedation (Hulland et al.; Pereira-Santos et al.). Also, it is important to understand that every patient has a different response to medication, so the gap between different levels of sedation may appear to be different in various organisms (Astramskaite' \& Juodz"balys). Nitrous oxide is an inhaled gas delivered with oxygen in a fixed ratio which can be titrated for sedation. Inhalation sedation with $\mathrm{N}_{2} \mathrm{O} / \mathrm{O}_{2}$ is the most common sedation technique used in dentistry in North America (Hulland et al.). Onset of action is rapid, and the gas has analgesic, sedative and anxiolytic effects. $\mathrm{N}_{2} \mathrm{O} / \mathrm{O}_{2}$ achieves a rapid peak clinical effect and is ultra-shortacting; effects dissipate rapidly after use is stopped; side effects are limited to the duration of inhalation and there is no need for a ride home. It is eliminated from the system when administration is stopped. Recognized adverse reactions are nausea, vomiting, and bizarre behavioral responses (Hulland et al.). The patients of this study did not present any side effects. Unpleasant side effects previously cited do not occur when titration is performed (Pereira-Santos et al.; Malamed \& Clark, 2003). In reviewing the literature, no studies were found comparing the outcomes of diazepam and $\mathrm{N}_{2} \mathrm{O} / \mathrm{O}_{2}$ for conscious sedation during third molar surgery.

Anxiety related to surgical dental procedures is a major health problem and presents a significant barrier to dental care (Kim et al.). Moreover, not all the procedures in the dental surgery cause the same levels of anxiety. Third molar extraction is related with dental anxiety and is reported to be the most anxiety-inducing procedure in oral surgery procedures (Astramskaite \& 
Juodz balys). Having an operation may cause anxiety, which can affect the physiology of a given patient and lead to changes in the systolic and diastolic blood pressures and heart rate (Göktay et al.). Another important factor is pain sensitivity that arises as a reaction to a physical or psychological negative stimulus, thus provoking stress in human bodies and also leading to hemodynamic alterations (Astramskaite" \& Juodžbalys). Therefore, anxiety reduction should be seen as an important benefit to prevent subsequent negative stress-related effects. In the literature, one may find several methods to relax the patient during a surgical dental procedure (Choi et al.). Our results showed that heart rate increased in the beginning of the surgery when the patient sat down at the dental chair and decresed at the end of the surgical procedure after suturing for both protocols. There were no significant diferences between the protocols in any of the operative periods, showing that the drugs had a similar effect on blood pressure and heart rate during third molar extraction. Specific events elicited an increase (sitting down in the dental chair, eyes being covered with surgical drapes, incision, flap-raising, application of local anesthetic and dental avulsion) or decrease (administration of additional anesthesia and end of the suture) in heart rate (Hollander et al.).

Monitoring the main vital signs during oral surgery allows the surgeon to immediately identify situations of increased risk before the surgical procedure, establish an early diagnosis and prevent possible complications, and operate with increased safety (Alemany-Martínez et al.). In this study, dyastolic and systolic blood pressure, heart rate and oxygen saturation were the vital signs monitored. A significant and sudden increase of the systolic and dyastolic blood pressure occurred at the beginning of the surgery when the patient sat down in the dental chair, which decreased and remained stable after that in both conscious sedation methods. This fact was also observed by Alemany-Martínez et al., who verified that blood pressure measurements were always higher at the start of the surgical procedure than at the end of the procedure. $\mathrm{N}_{2} \mathrm{O}$ has been reported to cause a decrease in both systolic and diastolic blood pressure (Hulland et al.). Anxiolytic treatments are associated with slower heart rate, lower systolic and diastolic blood pressure, and better cooperation from patients (Kim et al.; Göktay et al.; Fan et al.). However, even when these patients are sedated for a third molar extraction surgery, they may present an increase at heart rate and/or systolic and diastolic pressure at certain phases of the surgical procedure (Alemany-Martínez et al.; Hollander et al.; Dantas et al.). The changes in vital signs might be explained by endogenous adrenalin release caused by anxiety or pain reflex. Avoiding pain and minimizing patient anxiety is essential to the safety of outpatient clinical practice (Alemany-Martínez et al., 2008; Kim et al.; Hollander et al.). Third molar extraction is an invasive procedure which can produce pain during treatment and this negative stimulus increases endogenous adrenaline (Astramskaite' \& Juodz"balys). Local anesthesia is usually adequate to avoid pain during third molar surgery, however it may lead to an increase in vital signs values. The injection of the anesthetic solution may be painful and stressful (Kim et al.; Göktay et al.). Topical anesthetic gel was applied beforehand to minimize the the discomfort of injection pain.

Our findings showed that the oxygen saturation remained stable throughout surgery for both conscious sedation methods and proved to be safe from the clinical standpoint. However, an expected significant increase was noted in patients receiving $\mathrm{N}_{2} \mathrm{O} / \mathrm{O}_{2}$ since the patient sat down in the dental chair until the end of the suture. This finding is due to the nitrous oxide being titrated and mixed with oxygen in a maximous proportion of $70 \%$ of nitrous oxide to $30 \%$ of oxygen. In impacted mandibular third molar surgery, the use of oximetry in patients submitted to conscious sedation with benzodiazepines or inhalatory sedation with $\mathrm{N}_{2} \mathrm{O}$ / $\mathrm{O}_{2}$ is very important, as desaturation may occur. Respiratory depression is a common collateral effect of benzodiazepines (de Morais et al.; Dantas et al.). It also has been reported that $\mathrm{N} 2 \mathrm{O} / \mathrm{O} 2$ can cause oxygen desaturation.17 Desaturation is an event which may be followed by hypoxemia if it is not reversed and its prevention can be achieved through oxygen supplementation (de Morais et al.). Patients undergoing sedation should always have an oxygen saturation of $90 \%$ and ideally above this level (Wilson et al., 2003).

The current study found that the $\mathrm{N}_{2} \mathrm{O} / \mathrm{O}_{2}$ conscious sedation showed a significant decrease in the total duration of the surgery when compared to diazepam. This result might be related to the relationship between anxiety and surgical difficulty in impacted lower third molar extractions (Studer et al.; Aznar-Arasa et al.; Kazancioglu et al., 2017). In addition surgical dental treatments give rise to behavior changes, irritation, anger, and frustration on part of patients, which, in turn, may cause stress to the operating surgeon, impairing the surgical performance often leading to longer operative time (Aznar-Arasa et al.; Kazancioglu et al., 2015). The evidence from the results of this study suggests that both treatments 
CAVALCANTI, S. C. S. X. B.; CUNHA, F. C. \& LUZ, J. G. C. Effects of oral diazepam or inhalatory nitrous oxide-oxygen for conscious sedation during third molar surgery: A randomized controled trial, split mouth design. Int.J. Odontostomat., 14(1):19-26, 2020.

are effective in conscious sedation of the outpatients during third molar surgery but $\mathrm{N}_{2} \mathrm{O} / \mathrm{O}_{2}$ showed better outcomes with decreasing of operative time.

CAVALCANTI, S. C. S. X. B.; CUNHA, F. C. \& LUZ, J. G. C. Efectos del diazepam oral o la inhalación de óxido nitrosooxígeno para la sedación consciente durante la cirugía del tercer molar: un ensayo controlado aleatorio, diseño de boca dividida. Int. J. Odontostomat., 14(1):19-26, 2020.

RESUMEN: La ansiedad en la cirugía dentoalveolar puede conducir a alteraciones fisiológicas y de comportamiento en el paciente, constituyendo así un desafío frecuente para el cirujano maxilofacial. El objetivo de este estudio fue comparar el efecto del óxido nitroso inhalatorio con oxígeno $\left(\mathrm{N}_{2} \mathrm{O} / \mathrm{O}_{2}\right)$ y la sedación consciente oral con diazepam por médio de los signos vitales de pacientes sometidos a la extracción del tercer molar. Fueron incluídos pacientes ambulatoriales com necesidad de exodoncia de terceros molares inferiores bilaterales, parcialmente impactados, durante el período de un año. Cada paciente fue sometido a sedación consciente con diazepam oral o $\mathrm{N}_{2} \mathrm{O}_{/} \mathrm{O}_{2}$ por inhalación en un ensayo controlado aleatorio, diseño de boca dividida. La presión arterial sistólica y diastólica, la frecuencia cardíaca y la saturación de oxígeno en la sangre fueron medidos antes, al inicio y al final del procedimiento. Además, se registró la duración del procedimiento quirúrgico. Los datos de los signos vitales fueron enviados para análisis de varianza y la duración de la cirugía para la prueba t de Student pareada. Se estudiaron 25 pacientes ambulatorios sanos (13 mujeres y 12 hombres) con una edad media de 21,6 años. Al início hubo un aumento en la presión sistólica y diastólica y en la frecuencia cardíaca; estos valores disminuyeron y se estabilizaron al final del procedimiento quirúrgico en ambos tratamientos $(p<0,001)$, siendo más bajos en $\mathrm{N}_{2} \mathrm{O}$ / $\mathrm{O}_{2}$ pero sin diferencia entre los tratamientos. La duración del procedimiento quirúrgico fue menor y se produjo un aumento esperado de la oximetría bajo sedación con $\mathrm{N}_{2} \mathrm{O} / \mathrm{O}_{2}(p<0,001)$. Ambos tratamientos fueron efectivos para la sedación consciente, pero el $\mathrm{N}_{2} \mathrm{O} / \mathrm{O}_{2}$ mostró mejores resultados, principalmente en la duración de la cirugía.

PALABRAS CLAVE: sedación consciente, óxido nitroso, diazepam, tercer molar.

\section{REFERENCES}

Alemany-Martínez, A.; Valmaseda-Castellón, E.; Berini-Aytés, L. \& Gay-Escoda, C. Hemodynamic changes during the surgical removal of lower third molars. J. Oral Maxillofac. Surg., 66(3):45361, 2008.

Astramskaite, I. \& Juodzbalys, G. Scales used to rate adult patients' psycho-emotional status in tooth extraction procedures: a systematic review. Int. J. Oral Maxillofac. Surg., 46(7):886-98, 2017.
Astramskaite, I.; Poskevicius, L. \& Juodzbalys, G. Factors determining tooth extraction anxiety and fear in adult dental patients: a systematic review. Int. J. Oral Maxillofac. Surg., 45(12):1630-43, 2016.

Aznar-Arasa, L.; Figueiredo, R.; Valmaseda-Castellón, E. \& GayEscoda, C. Patient anxiety and surgical difficulty in impacted lower third molar extractions: a prospective cohort study. Int. J. Oral Maxillofac. Surg., 43(9):1131-6, 2014.

Choi, S. H.; Won, J. H.; Cha, J. Y. \& Hwang, C. J. Effect of audiovisual treatment information on relieving anxiety in patients undergoing impacted mandibular third molar removal. J. Oral Maxillofac. Surg., 73(11):2087-92, 2015.

Dantas, L. P.; de Oliveira-Ribeiro, A.; de Almeida-Souza, L. M. \& Groppo, F. C. Effects of passiflora incarnata and midazolam for control of anxiety in patients undergoing dental extraction. Med. Oral Patol. Oral Cir. Bucal, 22(1):e95-101, 2017.

de Morais, H. H.; Barbalho, J. C.; de Holanda Vasconcellos, R. J.; Landim, F. S.; da Costa Araújo, F. A. \& de Souza Dias, T. G. Comparative study of hemodynamic changes caused by diazepam and midazolam during third molar surgery: a randomized controlled trial. Oral Maxillofac. Surg., 19(3):26773, 2015.

Fan, T. W.; Ti, L. K. \& Islam, I. Comparison of dexmedetomidine and midazolam for conscious sedation in dental surgery monitored by bispectral index. Br. J. Oral Maxillofac. Surg., 51(5):428-33, 2013.

Göktay, O.; Satilmis, T.; Garip, H.; Gönül, O. \& Göker, K. A comparison of the effects of midazolam/fentanyl and midazolam/ tramadol for conscious intravenous sedation during third molar extraction. J. Oral Maxillofac. Surg., 69(6):1594-9, 2011.

Hollander, M. H.; Schortinghuis, J. \& Vissink, A. Changes in heart rate during third molar surgery. Int. J. Oral Maxillofac. Surg., 45(12):1652-7, 2016

Hulland, S. A.; Freilich, M. M. \& Sàndor, G. K. Nitrous oxide-oxygen or oral midazolam for pediatric outpatient sedation. Oral Surg. Oral Med. Oral Pathol. Oral Radiol. Endod., 93(6):643-6, 2002.

Inverso, G.; Dodson, T. B.; Gonzalez, M. L. \& Chuang, S. K. Complications of moderate sedation versus deep sedation/general anesthesia for adolescent patients undergoing third molar extraction. J. Oral Maxillofac. Surg., 74(3):474-9, 2016.

Jerjes, W.; Jerjes, W. K.; Swinson, B.; Kumar, S.; Leeson, R.; Wood, P. J.; Kattan, M. \& Hopper, C. Midazolam in the reduction of surgical stress: a randomized clinical trial. Oral Surg. Oral Med. Oral Pathol. Oral Radiol. Endod., 100(5):564-70, 2005.

Kazancioglu, H. O.; Dahhan, A. S. \& Acar, A. H. How could multimedia information about dental implant surgery effects patients' anxiety level? Med. Oral Patol. Oral Cir. Bucal, 22(1):e102-7, 2017.

Kazancioglu, H. O.; Tek, M.; Ezirganli, S. \& Demirtas, N. Does watching a video on third molar surgery increase patients' anxiety level? Oral Surg. Oral Med. Oral Pathol. Oral Radiol., 119(3):2727, 2015.

Kim, Y. K.; Kim, S. M. \& Myoung, H. Musical intervention reduces patients' anxiety in surgical extraction of an impacted mandibular third molar. J. Oral Maxillofac. Surg., 69(4):1036-45, 2011.

Lesaffre, E.; Philstrom, B.; Needleman, I. \& Worthington, H. The design and analysis of split-mouth studies: what statisticians and clinicians should know. Stat. Med., 28(28):3470-82, 2009.

Malamed, S. F. \& Clark, M. S. Nitrous oxide-oxygen: a new look at a very old technique. J. Calif. Dent. Assoc., 31(5):397-403, 2003.

Pell, G. J. \& Gregory, G. T. Report on a ten-year study of a tooth division technique for the removal of impacted teeth. Am. J. Orthod. Dentofac. Orthop., 28(11):B660-6, 1942.

Pereira-Santos, D.; Brêda-Júnior, M. A.; Ferraz, E. P.; Crippa, G. E.; de Oliveira, F. S. \& da Rocha-Barros, V. M. Study comparing midazolam and nitrous oxide in dental anxiety control. J. Craniofac. Surg., 24(5):1636-9, 2013. 
CAVALCANTI, S. C. S. X. B.; CUNHA, F. C. \& LUZ, J. G. C. Effects of oral diazepam or inhalatory nitrous oxide-oxygen for conscious sedation during third molar surgery: A randomized controled trial, split mouth design. Int.J. Odontostomat., 14(1):19-26, 2020.

Studer, F. R.; Grätz, K. W. \& Mutzbauer, T. S. Comparison of clonidine and midazolam as anxiolytic premedication before wisdom tooth surgery: a randomized, double-blind, crossover pilot study. Oral Maxillofac. Surg., 16(4):341-7, 2012.

Tanidir, A. N.; Atac, M. S. \& Karacelebi, E. Information given by multimedia: influence on anxiety about extraction of impacted wiidom teeth. Br. J. Oral Maxillofac. Surg., 54(6):652-7, 2016.

Tarazona, B.; Tarazona-Álvarez, P.; Peñarrocha-Oltra, D.; RojoMoreno, J. \& Peñarrocha-Diago, M. Anxiety before extraction of impacted lower third molars. Med. Oral Patol. Oral Cir. Bucal., 20(2):e246-50, 2015.

Wilson, K. E.; Girdler, N. M. \& Welbury, R. R. Randomized, controlled, cross-over clinical trial comparing intravenous midazolam sedation with nitrous oxide sedation in children undergoing dental extractions. Br. J. Anaesth., 91(6):850-6, 2003.

Young, E. R. Sedation: A Guide to Patient Management. $4^{\text {th }}$ ed. St. Louis (Missouri), Elsevier, 2005.
Corresponding author:

Samantha Cristine Santos Xisto Braga Cavalcanti.

Department of Oral and Maxillofacial Surgery.

School of Dentistry - University of São Paulo.

Av. Prof. Lineu Prestes, 2227

Cidade Universitária, 05508-900

São Paulo - SP

BRAZIL

E-mail: sacavalcanti@usp.br

Received: 14-05-2019

Accepted: 13-08-2019 